\title{
NAMING CUSTOMS AS AN INDICATION OF ASSIMILATION \\ A study of first names in the two Jewish congregations of Stockholm and Malmö 1895-1921*
}

\author{
Rita BredefeldT \\ Stockholm
}

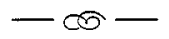

To catch a group of people in the middle of their process of assimilation confronts a scholar with a well-known problem of "translation". Every researcher has experience of the difficult task of interpreting traces that people leave behind and of trying to translate these traces into a comprehensive reconstruction of a disappeared reality. This paper deals with names as such traces. Or more precisely, the first names of Jewish children and their parents in two very different congregations in Sweden, namely, the orthodox congregation in Malmö and the liberal congregation in Stockholm during the period I895-I921.

Founded already at the end of the I8th century, the Jewish congregation of Stockholm soon developed a tradition of reform Judaism where "diversity in unity and unity in diversity" prevailed. ${ }^{1}$ A hundred years later in I871 a new congregation was founded in Malmö. It became the fifth in line and the most orthodox congregation in the country. At the turn of the century, around I900, both congregations received a relatively large group of immigrants from Eastern Europe and Tsarist Russia's Pale of Settlement. Considerably many came to the city of Lund that was included in the Malmö congregation. These poor and deeply religious Eastern Jews came to a fairly familiar orthodox environment. In Stockholm the Eastern Jews came to a liberal Jewish cultural milieu where assimilation had gone far. 
Most likely Jewish identity was defined partly in a different way in the orthodox congregation of Malmö than in the more liberal Stockholm congregation. What impact did the orthodox milieu in Malmö have for the reproduction of the traditional Jewish naming customs? Did the religious Eastern Jews, as their predecessors a hundred years before them, prefer to mark their integration and assimilation as quickly as possible or did they choose to emphasize their origin through Jewish names from one generation to another?

For ages the Jews in the diaspora have practiced a double naming custom. From the Middle Ages on, if not before, a double name standard became common practice. A Jew could have one Hebrew name within the congregation and another (secular) name in the outside world. In the synagogue, a Jew was called to different rituals by his/her Hebrew name (circumcision, reading the Torah, weddings, funerals etc). In contact with the outside society the Jews used their secular names in different transactions, be it in signing contracts or meeting people. Since all Jews had to be members of a congregation up to the I950s, it is most probable that the Jews in Malmö and Stockholm practiced this double standard during the period studied here. Jewish naming customs contain an element of "longue durée" (very long durability structure) of traditional biblical names and a changing element of secular names similar to those in society as a whole. This practice reveals a pragmatic attitude to maintain continuity within the Jewish tradition and at the same time to emphasize affiliation with the outside world. This paper will not deal with the Hebrew names inside the synagogue. In addition to that this tradition is difficult to pinpoint in primary material, it is not suited to measure a process of change, simply because of its unchanging character. And since other sources clearly have shown that Jews in Sweden (and elsewhere) have gone through a process of integration and assimilation during their 200-year residence in the country, it is the variable part of naming that is of interest here. So, what we really are studying is how the Jews viewed the outside world and how they wanted to be viewed by $i t$. The fear for anti-Semitism has most certainly also played a part in the choice of names. The Jews did not want to differ too much from the majority population so as to avoid anti-Semitism.

It is important to make it clear that Jewish names do not have any inherent quality of "Jewishness". They are simply "names common within the Jewish tradition", which mostly means biblical names, especially for the male population. The object of this study is the change in the use of the Jewish population's first names within the Swedish society and how we in that can discern a stronger (or weaker) wish to integrate into the majority society. Were most first names during the above-mentioned period Swedish? Or did some fami- 
lies prefer to mark their Jewish identity also in their contacts with the outside world?

The main primary material used is birth registers from both congregations for three five-year periods (1895-1899, 1906-1910 and 1917-1921). The population consists of all newborn Jewish children and their parents during this time which also coincides with the most intensive period of immigration of eastern Jews.

\section{EAstern JeWISH IMMigration to SWEDEN I870-I920}

Even if one includes the reproduction of the earlier settled "Western" Jews there is no doubt that the increase of the Jewish population during the later immigration wave was considerable. During the most important immigration years (1890-1920) the Jewish population increased by more than 3000 individuals. While the congregation of Malmö four-doubled its members from I870 to 1920 , the Stockholm congregation had a threefold increase during the same period. In absolute numbers the immigration to Stockholm was larger, but the share of Eastern Jewish immigrants to Malmö was greater. Together both congregations represented a share of $58 \%$ of all Jews in Sweden in 1920.

In the congregation of Malmö, most of the Eastern Jews settled in the city of Lund. They lived in a poorer part of Lund called "Nöden", together with many Swedish workers and artisans. One Swedish researcher calls this Jewish colony "a shtetl in Lund". ${ }^{2}$ In Stockholm the Eastern Jewish immigrants also settled down in the poorer (Southern) districts of town, not near the well-todo middle and upper-class "Western" Jews. The reaction of the latter Jewish group in both congregations against these poor, ill clad and "superstitious" Jews was of scepticism and fear. Neither wanted to be officially connected to this "ragged" and "ignorant" group, which radically challenged the identity of the established Jews in Malmö and Stockholm. This Jewish identity had been built up for generations as a respected economic and cultural elite. They were simply afraid to rouse new anti-Semitism by being connected to these people in an unfavourable way. This was a social, economic and cultural collision among the Jews themselves. It was a question of how the resident Jews saw upon themselves and wanted to be seen. 
Table I: The Jewish population in the congregations of Stockholm, Malmö and the whole of Sweden 1870-1920

\begin{tabular}{|c|c|c|c|}
\hline Year & Stockholm & Malmö* & Sweden \\
\hline $1870 / 7 x$ & 965 & 250 & I836 \\
\hline I880 & 1259 & & 2993 \\
\hline 1890 & I293 & & 3402 \\
\hline $1900 / 1901$ & 1630 & 569 & 3912 \\
\hline I9IO & 2628 & 637 & $6 \mathrm{~m} 2$ \\
\hline 1914 & & $86 I$ & \\
\hline 1920 & 2747 & 1000 & 6469 \\
\hline \multicolumn{4}{|c|}{ * The numbers for Malmö include Lund. } \\
\hline \multicolumn{4}{|c|}{$\begin{array}{l}\text { Sources: Stockholm: Dyrdak, A: Befolkningsstatistiska uppgifter I830-I930. Supplement to } \\
\text { Judarna i det svenska sambället I800-I950. Malmö: Malmö Stads Arsbok I913 och Ig20. Svenson, } \\
\text { A I995: Nöden-en shtetl i Lund, p 53. Zitomersky, J: "The Jewish Population in Sweden 1780- } \\
\text { I980. An Ethno-Demographic Study" in Broberg, Runblom, Tydén (eds) I988: Judiskt liv i } \\
\text { Norden. P I22. Bredefeldt, R I997: "Ekonomi och identitet: de svenska judarnas ekonomiska } \\
\text { verksamheter och självbild från 1800-talets andra hälft till 1930". Nordisk Judaistik Vol I8, No } \\
\text { I-2, p 35. }\end{array}$} \\
\hline
\end{tabular}

Still, this negative attitude had to be abandoned. The Eastern Jews had come to stay. Especially in Stockholm, the congregation members started a broad program to "civilize and modernize" the Eastern immigrants. In Lund the Jews felt they were so badly treated by their mother-congregation in Malmö that they in 1902 applied for the establishment of a separate congregation of their own. This was not granted, so they remained an isolated "annex" to the congregation in Malmö.

The situation of the immigrants in Stockholm and Malmö was in the beginning one of relative isolation. But in the beginning only. Soon enough the Eastern Jews also in Lund experienced the "typical" Jewish upward social mobilization and moved to other parts of Sweden. The Eastern Jews in Stockholm also became, after a generation or so, well integrated into both the congregation and Swedish society as a whole.

The congregation of Malmö was founded very shortly before immigration started and assimilation had not yet gone far. This was not the case in Stockholm. The congregation had existed nearly a hundred years with a Jewish population that had fought for its emancipation and achieved it. It had already gone through several phases of its assimilation. It is important to keep this in mind when comparing naming customs in these two very different 
congregations. Table 2 below shows the total number of individuals and names of newborn children and their parents in the congregations of Stockholm and Malmö during I895-I92I (i.e. all the investigated 5-year periods together).

Table 2: Individuals and names of newborn children and their parents in the congregations of Stockholm and Malmö I895-I92I

\begin{tabular}{lrr|rr} 
& Stockholm & & Malmö \\
\hline & Individuals & Names & Individuals & Names \\
Fathers* & 132 & 95 & 106 & $6 \mathrm{I}$ \\
Mothers* & I34 & I05 & 109 & 67 \\
Sons & 89 & 102 & 88 & $7 \mathrm{I}$ \\
Daughters & 84 & 79 & 96 & 69 \\
Total & 432 & $38 \mathrm{I}$ & 399 & 268
\end{tabular}

*That fathers in some cases are fewer than mothers is due to a note in the primary material that the father is "unknown".

Sources: Malmö Stadsarkiv, Födelse- och dopbok I895-1920, 1921-1942 för Mosaiska Församlingen i Malmö CI:I,2. Stockholms Judiska Församlings arkiv, Födelsebok x895-1924.

As we can see for the whole period, there was a difference in the number of names per person between the congregations: Malmö had fewer names per person and probably a less varied naming structure than Stockholm. We can also see a difference between generations: the parents had fewer names per person than their children, the younger generation a larger number of names than their parents. There was also a gender difference: fathers had fewer names than mothers and vice versa in the younger generation, so that the daughters had fewer names than the sons.

The difference between the congregations is considerable. Data shows that while $63 \%$ of the newborn Jewish children in Stockholm had two or more names, $63 \%$ of the children in Malmö had only one name. This obviously has to do with the large domestic Jewish group in Stockholm, that during the years had developed a preference of several names. That this is really a fact, can be seen, when they are compared to the immigrant group during the same period: $58 \%$ of the latter had only one first name, while only $35 \%$ of the former had one name. Equivalent primary material cannot be found for Malmö, so we cannot separate the Western Jewish group from the Eastern Jewish one. But since the latter most probably became the largest group in the Malmö congregation (see table I), it can easily be understood that the naming custom of one name dominated there. On the contrary, in Stockholm, there was obviously greater acceptance for several names, as a rule non-Jewish ones. 
Table 3: Jewish names among newborn children and their parents in the Jewish congregations of Malmö and Stockholm $1895-1921$ (percent)

$\begin{array}{lrrrrr} & \text { Fathers } & \text { Sons } & \text { Mothers } & \text { Daughters } & \text { Total } \\ & \% & \% & \% & \% & \% \\ \text { Stockholm } & 47 & 20 & 23 & 12 & 28 \\ \text { Malmö } & 67 & 5 \mathrm{I} & 46 & 31 & 49\end{array}$

The table shows the share of individuals with Jewish names. They are counted even if they had the same name or also had other non-Jewish names.

Sources: Födelsebok 1895-1924 Stockholms Judiska Församlings arkiv. Födelse- och dopbok 1895-I920, 1921-r942, Malmö Stadsarkiv.

The diagram above shows that there was a certain difference between naming customs in the liberal congregation of Stockholm and the orthodox Malmö congregation. In the former a majority of all categories of individuals had non-Jewish names, in the latter the majority of fathers and sons had Jewish names. A greater percentage of mothers and daughters in Malmö than in Stockholm had Jewish names, even if it is not the majority. The orthodox environment obviously does make a certain difference in naming customs.

Still, the similarities seem to dominate. These similarities are connected to gender and generation. Fathers and sons in both congregations have more often Jewish names than mothers and daughters. Mainly men were considered to be the transmitters of the naming tradition. This is a custom that goes way back at least to the Middle Ages. Women's names have not as a rule had a religious character. Even in orthodox congregations women's names bore less religious connotations. It has been explained by the fact that women did not participate in the traditional activities of the synagogue, they were not religiously educated traditionbearers. With the exception of the matriarchs Ester and Hanna, most women had names showing happiness, holiness, riches, beauty, colours, stars etc. (Bona, Gracia, Linda, Clara, Blanca, Vida, Allegra, Simha, Dolsa, Perla, Estrella etc). Men's names have traditionally been taken from the Bible, the patriarchs, the twelve tribes, the prophets, etc. Most men's names carried a religious message. Still researchers have found traces of assimilation already in the late Ottoman Empire under the Igth century, with an increase in French and other European names among the Jews, even if the majority still had Jewish names.

There is a difference between the generations that can be interpreted as an active expression to integrate into Swedish society. Sons and daughters in both congregations have less Jewish names than their parents.

So even if there is a marked difference between an orthodox and a liberal congregation, the similarities are as strong, if not even stronger than the differences. 


\section{These ARE THE NAMES}

An investigation of what Jewish names the fathers and mothers had, shows a limited repertoire of Jewish names for both: In Malmö eight (8) Jewish names circulated among $45 \%$ of the fathers (Abraham, Salomon, Aron, Isak, Jacob, David, Josef and Moses). A third of the mothers shared six Jewish (6) names (Sara, Rebecka, Ester, Rifka, Rakel, Chaja). In Stockholm the situation was similar among the parents that had Jewish names: the range of names was limited.

I have also investigated what preference Jewish parents could have had when they gave their children two or more names. Did they want to mark that the child had both a Swedish and a Jewish identity? The result shows first, that very few in both congregations had two Jewish names. Second, the results show that a preference for one Jewish and one Swedish name was higher than for two Jewish names, but also very low. In Malmö only $9 \%$ of all newborn children with several names had these two types of names. Their names could be Ruben Magnus, Moses Bertil or Rakel Thora. In Stockholm they were 8\% and were named Levy Gustaf, Samuel Arne, Josef Åke, Jacob Göran or Ester Brita and Ester Barbro.

Of all children that had two names $79 \%$ had both names non-Jewish in Stockholm and $50 \%$ in Malmö. When the parents gave themselves the possibility to give their children two names, they preferred two non-Jewish names for their children and very few marked the double identity in names. The parents wanted non-Jewish names in their contacts with the Swedish society. But even if the group with two Jewish names was the smallest in both congregations, there was a difference between them. While in Malmö a higher percentage of parents wanted to hold on to Jewish names in different combinations, the Stockholm parents in general abandoned this option.

\section{no}

The declining preference to name newborn children with Jewish names can also be seen in time, when we look at every 5-year period separately. Table 3 below shows a rise in Jewish names in both congregations during the most intensive 5-year period (1905-1910) of immigration. It is also clear that there is a drop in Jewish names after that. Newly immigrated parents seem to have wanted to mark the Jewish identity of their children, while this preference seems to decline the longer they stayed in the country. This is true in both congregations. This is an indication of a common desire to be regarded as Swedish citizens like everyone else, irrespective of the religious or cultural milieu of the congregation. 
Table 4: Newborn sons and daughters with Jewish names in the congregations of Malmö and Stockholm I895-I92I

\begin{tabular}{lrr|rr}
\multicolumn{3}{c}{ Malmö } & \multicolumn{2}{c}{ Stockholm } \\
\hline Period & Sons & Daughters & Sons & Daughters \\
I895-I899 & 3 of $8(38 \%)$ & 4 of $13(31 \%)$ & 7 of $30(23 \%)$ & 2 of $29(7 \%)$ \\
I9O6-I9IO 29 of $49(59 \%)$ & 2 I of $56(38 \%)$ & 8 of $31(26)$ & 5 of $30(\mathrm{I} 7 \%)$ \\
I9I7-I92I & I3 of 3 I $(42 \%)$ & 5 of $27(\mathrm{I} 9 \%)$ & 3 of $28(\mathrm{II} \%)$ & 3 of $25(\mathrm{I} 2 \%)$ \\
Total & 45 of $88(5 \mathrm{I} \%)$ & 30 of $96(3 \mathrm{I} \%)$ & I8 of $89(20 \%)$ & I0 of $84(\mathrm{I} 2 \%)$
\end{tabular}

The table shows the number of individuals with Jewish names, even if they had the same name or also had other names.

Source: Stockholms Judiska Församlings arkiv, Födelsebok 1895-I924. Malmö Stadsarkiv, Födelse- och dopbok I895-1920, I92I-1942 i Malmö Mosaiska Församling.

The overall picture shows, that even if the share of Jewish names in the orthodox Malmö congregation is larger than in the liberal Stockholm congregation, there is a fundamental similarity away from traditional Jewish names and towards more non-Jewish ones.

What about the non-Jewish names? Were they all Swedish? And if not, what was the origin of the other non-Jewish names?

Table s: Origin of names of newborn children and their parents in the Jewish congregations of Malmö and Stockholm I895-I92I (percent)

$\begin{array}{lrr}\text { Origin of name } & \text { Malmö } & \text { Stockholm } \\ & \% & \% \\ \text { Jewish } & 38 & \text { I9 } \\ \text { Swedish } & 28 & 4 \mathbf{1} \\ \text { Anglo-Saxon } & \text { I5 } & 16 \\ \text { German } & 9 & 15 \\ \text { Other } & \text { IO } & 9\end{array}$

Observe that the table shows shares of names not individuals, as in tables 3 and 4 .

Sources: Stockholms Judiska Församlings arkiv. Födelsebok r895-1924. Malmö Stadsarkiv. Födelse- och dopbok I895-1920, I92I-1942 för Malmö Mosaiska Församling.

All the 5-year periods together mark the difference between the two congregations as in table 5. Here we see that taken together the congregation in Malmö had $38 \%$ Jewish names and $28 \%$ Swedish names. The picture is reversed for 
the congregation of Stockholm with $19 \%$ Jewish names and $41 \%$ Swedish ones. When we look at each 5-year period separately, we see the similarity in the drop in Jewish names in both congregations after I9Io (see table 4). Swedish names could be Brita, Frida, Selma, Karin, Hjördis and even Maria for the daughters and Björn, Bertil, Börje, Nisse, Johan and Gösta for the sons. Anglo-Saxon names such as Betty, Doris, Alice, Mary and Vivian for the daughters and George, Harry, James, Charles and John for the sons. The sons had German names such as Fritz, Ernst, Adolf, Manfred, Sigfrid, Maximilian and Moritz, while the daughters seldom hade German names at all. One might guess that the non-Jewish names that were not Swedish could have been names of deceased grandparents.

If we look at all names as in table 5 , we can see that $38 \%$ of all names in Malmö were Jewish and $19 \%$ of all names in Stockholm were Jewish. But if we look at all individuals as in table 3 , we can see that $49 \%$ of the individuals in Malmö had Jewish names and $28 \%$ of the individuals in Stockholm had Jewish names. This is due to the fact that many individuals had the same Jewish names. So, while all individuals with the same Jewish name were counted, every Jewish name was counted only once.

\section{Summary}

An important conclusion of this study is that, even if there is a certain difference between the two congregations (the share of individuals with Jewish names is higher in Malmö than in Stockholm), the main impression of the naming custom is that Jews in both congregations wanted to mark their will to integrate into Swedish society. In this case, the congregation milieu was not of decisive importance. We can see a drop in Jewish names shortly after the most intensive immigration period (I906-I9IO) of orthodox Eastern Jews in both Malmö and Stockholm. Non-Jewish names dominate so strongly in the congregation of Stockholm because of its long history and liberal traditions. The middle and upper-class Jews in Stockholm had for generations built up an identity of a well-integrated cultural and economic elite. This of course also manifests itself in their larger shares of secular names.

The difference between generations is a similar phenomenon in both congregations. The parents had more often Jewish names than their children and this was more so in Malmö than in Stockholm. The children had generally a more varied name structure concerning both the variety and the number of names. Here also, there was a difference between Malmö and Stockholm, so that newborn in the former congregation more often had only one name and the newborn in the latter more often had two names. 
Another similarity between the congregations is the gender difference. Fathers and sons had more often Jewish names than mothers and daughters. Men seem to be the main bearers of tradition when it comes to naming customs. Daughters have more often Swedish and Anglo-Saxon names, while sons have more often German names. One might guess that the non-Jewish names that were not Swedish were names of deceased grandparents.

The difference in the naming customs between the two congregations has also to be taken into consideration. A smaller variety of names and a larger amount of traditional Jewish names are more easily reproduced in a socially and economically homogenous, more isolated Jewish environment like the orthodox milieu in Malmö, especially in Lund. In a more mixed environment, with more contacts with the "outside", a growing similarity both socially and economically with the majority population, naming customs seem to become more varied.

On the other hand, we know that different groups of people in modern times are seldom totally isolated. They may be well aware of the customs of the surrounding majority population but still prefer to reject impulses from the outside and keep on reproducing old traditions.

In this case, it seems that in the long run, the Jewish minority wanted to be much like the Swedish majority. While some still marked their Jewish identity with a Jewish name, a growing group marked its will of integration and assimilation.

\section{Notes}

* This paper has been written within the project "Jewish Life in Sweden I860-1930. Economy and Identity in a Nordic Perspective" financed by the Swedish Council for Social Research.

I. Glück, David-Neuman, Aron-Stare, Jacqueline (eds.) x998: Det judiska Stockholm, 2I, a citation from Rabbi Leo Baeck.

2. Svenson, Anna I995: "Nöden - en shtetl i Lund". Gamla Lund Föreningen för bevarande av stadens minnen. Arsskrift 77 . Lund.

\section{SAMMANFATTNING}

Artikeln är en studie av förnamnsskicket i två helt olika typer av judiska församlingar: den ortodoxa församlingen i Malmö och den liberala församlingen i Stockholm åren I895-I921. Ur Födelseböcker för de tre femårsperioderna I895-1899, 1906-1910 och 19I7-I921 har samtliga nyfödda och deras 
förnamn kartlagts inom respektive församling. Syftet är att undersöka hur den judiska gruppens assimileringsprocess kom till uttryck i valet av förnamn till nyfödda barn inom församlingarna under en period av stark invandring av s.k. Östjudar från Tsarryssland, Polen och Baltikum.

Stockholmsförsamlingen bildades redan vid slutet av 1700-talet och blev ganska snart en enhetsförsamling, där ingen åsiktsriktning fick dominera över andra. Hundra år senare $187 \mathrm{x}$ bildades landets femte och mest ortodoxa judiska församling i Malmö. Under åren kring sekelskiftet r9oo fick båda församlingarna ta emot en relativt stor grupp östjudiska immigranter. Av olika anledningar kom en stor grupp östjudar, som egentligen tillhörde malmöförsamlingen, att hålla sig nästan helt för sig själv i Lund. De fattiga och djupt religiösa östjudarna kom till en redan ortodox församlingsmiljö där. I Stockholm kom östjudarna till en liberal judisk kulturmiljö där assimileringen redan nått långt.

Det som studeras här är inte den inom synagogan sedan århundraden använda namntraditionen av hebreiska namn, eftersom den är svårfångad i källorna och dessutom inte lämpad som mätare av assimilering på grund av sin oföränderlighet. Undersökningen omfattar de namn man valde till sina barn $i$ kontakterna med det omgivande samhället. Med andra ord visar namnen bur judarna betraktade omvärlden och hur de ville bli betraktade av den. Hur stor betydelse hade den ortodoxa miljön i malmöförsamlingen för reproduktionen av det traditionellt judiska namnskicket? Ville de religiösa östjudarna, liksom de hundra år tidigare invandrade västjudarna, integreras och assimileras så fort som möjligt eller ville de i högre grad markera sin judiska särart genom de personnamn som gick vidare till nya generationer?

Resultaten visar, att även om det fanns en viss skillnad mellan de två församlingarna (andelen individer med judiska namn är större i Malmö än i Stockholm), blir huvudintrycket av det tillämpade namnskicket att judarna inom båda församlingarna ville markera sin vilja att bli integrerade i det svenska samhället. Både i Malmö och Stockholm kan man se en tydlig uppgång av judiska namn under den intensivaste invandringsperioden 1906-I910 samtidigt som man direkt efter denna period ser en tydlig nedgang av dessa namn och en snabb ökning av icke-judiska namn, företrädesvis svenska. För denna huvudtendens hade inte församlingsmiljön någon avgörande betydelse. De icke-judiska namnen dominerar stort i Stockholm på grund av församlingens långa historia och liberala traditioner. Medel- och överklassjudar i huvudstaden hade under flera generationer byggt upp en identitet av en välintegrerad ekonomisk och kulturell elit. En annan gemensam utveckling hos båda församlingarna var skillnaden mellan generationerna: föräldrarna hade oftare judiska namn än barnen och detta i högre grad i Malmö än i Stock- 
holm. Barnen hade generellt också flera namn än föräldrarna. Däremot hade barnen i Malmö färre namn än barnen. i Stockholm. Ytterligare ett gemensamt drag mellan församlingarna var skillnaden mellan könen: fäder och söner hade oftare judiska namn än mödrar och döttrar. Männen verkar betraktas som traditionsbärarna inom detta område. Bland de icke-judiska namnen hade döttrar oftare svenska och anglosaxiska namn, medan sönerna oftare hade tyska namn. En gissning är att de icke-judiska namnen, som inte var svenska, kunde ha varit ärvda namn från avlidna far- och morföräldrar.

Mindre namnvariation och större andelar av traditionella judiska namn kan tydligen lättare reproduceras i en mera isolerad judisk miljö såsom inom malmöförsamlingens "Lund-annex". I en mera blandad miljö, med större kontaktytor och likhet med det omgivande majoritetssamhället skapas ett mera varierat namnskick. Samtidigt vet vi att olika minoritetsgrupper sällan är helt isolerade. De kan vara mycket väl medvetna om majoritetens namnskick, men föredra att avvisa impulserna utifrån och fortsätter att reproducera gamla traditioner. Medan en minoritet fortsatte att markera sin "judiskhet" inom namnskicket, visar sig huvudtendensen dock vara att den judiska minoriteten inte ville avvika från det omgivande samhällets namnskick: man markerade sin vilja att integreras och assimileras i det svenska samhället. 